Article

\title{
G6PD Status in Patients with Presenile And Senile Cataract
}

\author{
Farzana Yasmin ${ }^{1}$, Noorzahan Begum², Sultana Ferdousi ${ }^{3}$
}

\begin{abstract}
Background: Glucose-6-phosphate dehydrogenase (G6PD) deficiency is one of the common enzymopathy and may be one of the risk factor for both presenile and senile cataract. Objective: To observe erythrocyte G6PD level in male patients with presenile and senile cataract in order to find out their enzyme status. Methods: This cross sectional study was carried out in the Department of Physiology, Bangabandhu Sheikh Mujib Medical University (BSMMU), Shahbag Dhaka between $1^{\text {st }}$ July 2009 and 30 ${ }^{\text {th }}$ June 2010. 60 male patients with presenile and senile cataract were included in the study group (Group-B). They were selected from Out patient Department (OPD) of Ophthalmology of BSMMU in Dhaka City. For comparison age matched 60 apparently healthy male without cataract (Group A) were also studied. According to age both study \& control group were again subdivided in to Group $B_{1} \& A_{1}$ (presenile,aged $40-60$ years) and Group $B_{2} \& A_{2}$ (senile, aged $>60$ years). Erythrocyte G6PD level was measured by Spectrophotometric method. Data were analyzed by independent sample t test, ANOVA, Chi-square test as applicable. Results: Mean erythrocyte G6PD level was significantly lower $(\mathrm{P}<0.01)$ in the presenile and senile cataractous groups compared to their corresponding noncataractous subjects. However $26.7 \%$ cataractous patients in presenile and $6.7 \%$ in senile group were G6PD deficient. Conclusion: Erythrocyte G6PD deficiency may be present in both presenile and senile cataract but more marked in presenile cataract patients.
\end{abstract}

Key words: G6PD, Cataract.

J Bangladesh Soc Physiol. 2011 June; 6(1): 1-4 For author affiliations, see end of text.

http://www.banglajol.info/index.php/JBSP

\section{Introduction}

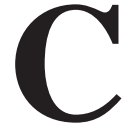

ataract has been recognized by World Health Organization (WHO), as prime cause of impaired vision and blindness affecting more than 17 million people throughout world $^{1}$. Individuals with cataract at the age range of 40 to 60 years and above 60 year of age respectively was termed as presenile and senile cataract ${ }^{6,9}$.

Pathophysiology of cataract involved denaturation and cross linking of lens proteins, with loss of transparency which is aggravated by its oxidative damage. Recently, it has been reported that raised $\mathrm{H}_{2} \mathrm{O}_{2}$ may cause development of cataract in G6PD deficient subjects ${ }^{10}$.

J Bangladesh Soc Physiol. 2011 June; 6(1): 1-4
G6PD deficiency is predominantly a male syndrome. Since male possess only one copy of the gene encoding for G6PD, they are either normal or G6PD deficient. On the other hand, females are normal, heterozygous or homozygous. In the affected subject of the Mediterranean type, the enzyme deficiency occurs not only in the RBC but also in the lens in which this enzyme play an important role in maintaining transparency ${ }^{6}$.

Orzalesi, Sorcinelli and Gulso found that significantly higher prevalent G6PD deficiency among the patients with cataract ${ }^{6}$. 


\section{Article}

G6PD Status in Patients with Presenile And Senile Cataract

Bhatia, Patel and Dubley observed that the frequency of G6PD deficiency was higher in the presenile group but progressively lower in the senile group ${ }^{1}$.

Again, Chen et al. reported that both in RBC and lens, presenile cataractous groups had lower G6PD level ${ }^{2}$.

Cataract comprises $80 \%$ of avoidable blindness in Bangladesh ${ }^{4}$.In our country many people are suffering from cataract. But there is lack of information regarding G6PD enzyme status in these cataractous patients which may have some contribution in the disease. Therefore, the present study was carried out to observe erythrocyte G6PD status in presenile cataractous patients in order to find out the relationship between this enzyme deficiency and the development of presenile cataract.

\section{Methods}

This Cross-sectional study was carried out in the Department of Physiology, BSMMU, Dhaka between July 2009 and June 2010. Total number of 120 male subjects of 40-70 years of age were selected for the study. 60 male patients with cataract were enrolled for the study group (GroupB) from the Out Patients Department (OPD) of Bangabandhu Sheikh Mujib Medical University (BSMMU), Shahbag. 60 age, BMI, sex matched apparently healthy noncataractous subjects were randomly selected from the community and were taken as control(GroupA). Based on the age both study and control group were subdivided in to group $B_{1}$ (presenile cataractous,aged $40-60$ years) and $A_{1}$ ((presenile non cataractous,aged 40-60 years) and Group $\mathrm{B}_{2}$ (senile cataractous, aged $>60$ years) \& $\mathrm{A}_{2}$ (senile noncataractous, aged $>60$ years). Subjects with traumatic eye, diabetes mellitus, radiation injured eye, hyperparathyroidism, hypertension, glaucoma and steroid users were excluded from the study. Protocol of this study was approved by ethical review committee of BSMMU.After selection of the subjects the purpose and benefits of the study were explained to each subject and informed written consent was taken from them.

A detailed personal, medical, family, socioeconomic, drug history was recorded in a prefixed questionnaire. Thorough physical examinations including slit lamp examination of eye of all subjects were done to confirm the presence of cataract. Then $3 \mathrm{ml}$ of venous blood was collected and erythrocyte G6PD level was measured by sphectrophotometric method. The data were expressed as Mean $\pm \mathrm{SD}$ and was analyzed by unpaired Student's ' $t$ 'test, ANOVA and Chi-square test as applicable.

\section{Results}

Anthropometric data of study subjects are presented in Table I. Both groups were similar in respective to age and BMI.Again mean erythrocyte G6PD level was significantly lower $(\mathrm{P}<0.01)$ in group $\mathrm{B}_{1}$ and $\mathrm{B}_{2}$ than those of group $\mathrm{A}_{1}$ and $\mathrm{A}_{2}$ (Figure 1 ).

Table-I : Age and BMI in different groups of subjects ( $\mathrm{n}=120)$.

\begin{tabular}{lccc}
\hline Groups & $\mathrm{n}$ & Age $(\mathrm{yrs})$ & $\mathrm{BMI}\left(\mathrm{kg} / \mathrm{m}^{2}\right)$ \\
\hline $\mathrm{A}_{1}$ & 30 & $49.80 \pm 3.52$ & $23.55 \pm 0.74$ \\
$\mathrm{~A}_{2}$ & 30 & $62.87 \pm 1.36$ & $23.64 \pm 0.77$ \\
$\mathrm{~B}_{1}$ & 30 & $50.70 \pm 3.35$ & $23.88 \pm 0.76$ \\
$\mathrm{~B}_{2}$ & 30 & $63.47 \pm 1.55$ & $23.68 \pm 0.84$ \\
\hline
\end{tabular}

Statistical Analysis:

\begin{tabular}{lcc}
\hline Groups & \multicolumn{2}{c}{ p value } \\
\hline $\mathrm{A}_{1}$ vs $\mathrm{A}_{2}$ vs $\mathrm{B}_{1}$ vs $\mathrm{B}_{2}$ & $0.001^{* *}$ & $0.402^{\text {ns }}$ \\
$\mathrm{A}_{1}$ vs $\mathrm{B}_{1}$ & $0.315^{\mathrm{ns}}$ & $0.089^{\text {ns }}$ \\
$\mathrm{A}_{2}$ vs $\mathrm{B}_{2}$ & $0.116^{\text {ns }}$ & $0.867^{\text {ns }}$ \\
\hline
\end{tabular}

Data are expressed as Mean \pm SD.

Group A = Non cataractous subjects (Control group).

Group $A_{1}=$ Presenile

Group $A_{2}=$ Senile

Group B = Cataractous patients (Study group).

Group $\mathrm{B}_{1}=$ Presenile

Group $\mathrm{B}_{2}=$ Senile

$n s=$ Non significant $(p>0.05)$

J Bangladesh Soc Physiol. 2011 June; 6(1): 1-4 


\section{Article}

G6PD Status in Patients with Presenile And Senile Cataract

No control subjects were found G6PD deficients.Again prevalence of G6PD deficiency is higher in presenile than that of senile cataractous group but difference was not significant.(Figure 2)

$8(26.7 \%)$ of the presenile catractous subjects had erythrocyte G6PD level below $<245 \mathrm{mU} / 10^{9}$ RBC but no deficient subjects were found in senile cataractous group in these ranges. However, 2 (6.7\%) of senile cataractous subjects had erythrocyte G6PD level below $<200 \mathrm{mU} / 10^{9}$ RBC but no deficient subjects were found in presenile cataractous group in these ranges (Figure 3).

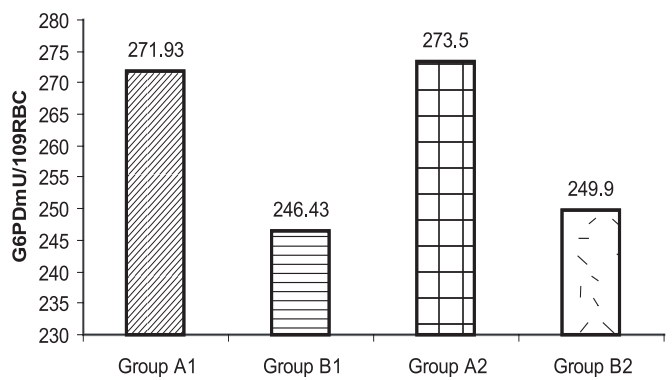

Figure 1: Mean erythrocyte G6PD level in different groups of subjects $(n=120)$

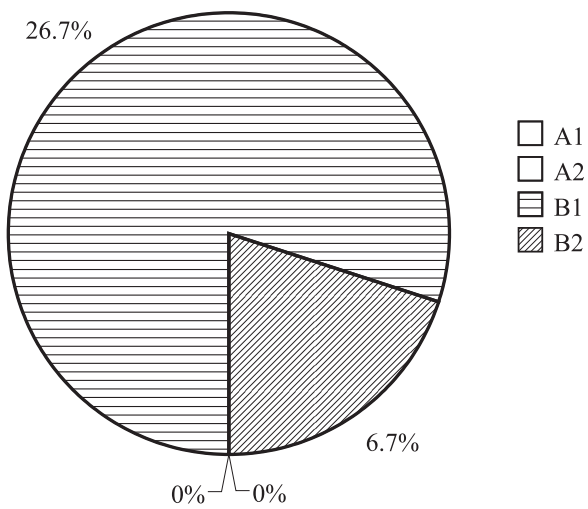

Figure 2 : Distribution of the subjects by G6PD deficiency in different groups $(\mathrm{n}=120)$.

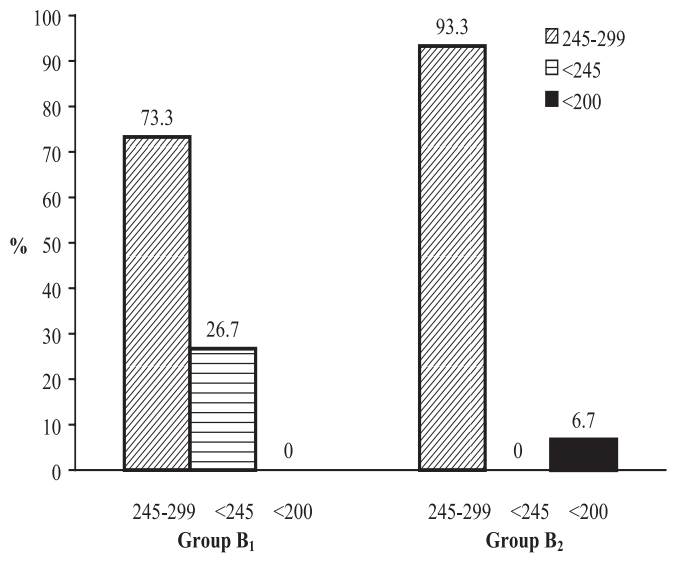

Figure 3 : Distribution of the subjects by erythrocyte G6PD level in cataractous groups $(\mathrm{n}=60)$.

\section{Discussion}

In the present study the erythrocyte G6PD status was studied in presenile and senile cataractous male patients. The values of erythrocyte G6PD level in noncataractous subjects in this study were almost similar to the findings of control subjects reported by various investigators of different countries ${ }^{1,11,12}$.

Again, mean erythrocyte G6PD level in cataractous patients were significantly lower than those of noncatarctous subjects which is also consistent with findings of other investigators 5,6,11-12. In addition, the mean G6PD level was close to the lower limit of reference value.

In this study percentages of the erythrocyte G6PD deficiency in presenile and senile cataractous patients were also observed. Total $33.4 \%$ enzyme deficiency found in both the cataractous groups were almost similar to the findings reported by various investigators of different countries ${ }^{6,11}$.In addition, no G6PD deficiency was found in non cataractous healthy subjects.

Various researchers of different countries suggested that in cataract high molecular weight 
Article

proteins are formed following extensive oxidation which causes precipitation of lens proteins and thereby causing loss of transparency ${ }^{7}$.

It was also suggested that G6PD deficiency affects pentose phosphate pathway, resulting in inavailability of ribose for lens protein synthesis ${ }^{6}$.

Oxidation of ÉSH groups of $\mathrm{Na}^{+}-\mathrm{K}^{+}$ATPase causes lenticular accumulation of $\mathrm{Na}^{+}, \mathrm{ClÉ}, \mathrm{Ca}^{++}$ which leads to cellular hydration, Swelling, rupture and followed by opacity of lens ${ }^{11,12}$.In G6PD deficiency due to loss of NADPH and GSH production, there is increased susceptibility of the lens to oxidative insult and subsequent loss of lens transparency ${ }^{5}$.

In the present study, lowered erythrocyte G6PD level in presenile and senile catractous patients may be suggestive of increased susceptibility of the lens to oxidative injury associated with deficiency of antioxidants in the ocular lens.

\section{Conclusion}

Therefore, this study concludes that G6PD deficiency may be a risk factor for development of cataract in presenile and senile age group.

\section{Acknowledgement}

Authors of this study are thankful to the of Department of Ophthalmology, BSMMU for their cooperation .

\section{Author's affiliations}

*1. Farzana Yasmin, Lecturer Department of Physiology, Bangladesh Medical College, Dhaka. E mail:fyasminbmc@gmail.com

2 Noorzahan Begum, Professor Department of Physiology, Bangabandhau Sheikh Mujib Medical University (BSMMU), Bangladesh, Email: noorzahan52@gmail.com

3. Sultana Ferdousi, Associate professor, Department of Physiology, Bangabandhau Sheikh Mujib Medical University (BSMMU), Bangladesh, Email: sferdousiratna@gmail.com

*for correspondence

\section{References}

1. Bhatia RPS, Patel R, Dubey B. Senile cataract and glucose-6-phosphate dehydrogenase deficiency in Indians. Trop Geogr Med 1990; 42:349-51.
G6PD Status in Patients with Presenile And Senile Cataract

2. Chen Y, Zeng L,Ma Q,Su W,Mao W.The Study of G6PD in erythrocyte and lens in Senile and Presenile cataract.Yan Ke Xue Bao 1992;8(1):12-5.

3. Hart WM . Adler's Physiology of the Eye. $9^{\text {th }}$ ed . USA : Mosby Year Book ;1992. 377p.

4. Khan AK. Microcredit cataract surgery:My experience and new dimensions in Bangladesh. J Bangladesh Soc Ophthalmol 2006;33(2):16093259.

5. Moro F, Gorgone G, Livolti S, Cavallaro No, Faro S, Curreri R, Mollica F. Glucose-6-phosphate dehydrogenasedeficiency and incidence of cataract in Sicily. Ophthalmic paediatr and Genet 1985; 5(3):197-200.

6. Orzalesi N, Sorcinelli R, Gulso G. Increased incidence of cataracts In male subjects deficient in glucose-6phosphate dehydrogenas.Arch ophthalmol 1981; 99: 69-70.

7. Orzalesi N, Fossarello M, Soreinelli R Schlich U. The relationship between glucose-6-phosphate dehydrogenase deficiency and Cataracts in Sardinia. An epidemological and biochemical Study. Doc ophthalmol 1984; 57(3): 187-201.

8. Rosenfold SI, Bechler MH, Bobrow CJ, Bradford CA, Glasser D, Berestka SJ.Lens and Cataract. Section-11.USA: American academy of Ophthalmology; 2004. 71-72 p.

9. Sihota R, Tandon R. Parsons Diseases of the Eye.20 th ed. New Delhi: Elsevier; 2007 . 248,251 p.

10. Vanella A, Gorgone G, Cavallaro N. castorina C, Campisi A, Di Giacomo C, Bousquet E, Livolti S, Mollia F, Superoxide dismutase activity and Reduced glutathione content in catractous lens of patients with glucose-6-phosphate dehydrogenase deficiency. Ophthalmic paediatr and Genet 1987; 8(3): 19195.

11. Yuregir G, Varinli I; Donma O, glucose-6phosphate dehydrogenase deficiency both in red blood cells and lenses of the Normal and Cataractous native population of Cukurova, the Southern part of Turkey Part I. Ophthalmic Res 1989; 21 (3): 155-7.

12. Yuregir G, Varinli I, Donma O, glucose-6phosphate dehydrogenase deficiency both in red blood cells and lenses of the Normal and Cataractous native population of Cukurova, the Southern part of Turkey Part- II. Ophthalmic Res 1989; 21 (3): 158-61.

J Bangladesh Soc Physiol. 2011 June; 6(1): 